\section{A New Organic Radical Reaction involving No Free Valence}

THe discovery of a fundamentally new type of organic radical reactions involving no unpaired electron has boen already reported ${ }^{1-3}$. The work recorded here was concerned with a reaction between a free radical, triacetoneaminoxyl and the Grignard reagent. The reaction proceeding with conservation of free valence yielded a new organic free radical with a hydroxyl group:<smiles>CCN1OC1(Br)C1(C)CC(C)(C)N(O)C(C)(O)C1</smiles>

After distillation in vacuum, the crude product appeared as a bright red oily substance readily soluble in water and in organic solvents. Analysis by means of paper chromatography has shown that the oil was a mixture of two radicals: 2,2,6,6-tetramethyl-4-ethyl-4-hydroxypiperidinoxyl and triacetoneaminoxyl (Fig. 1).

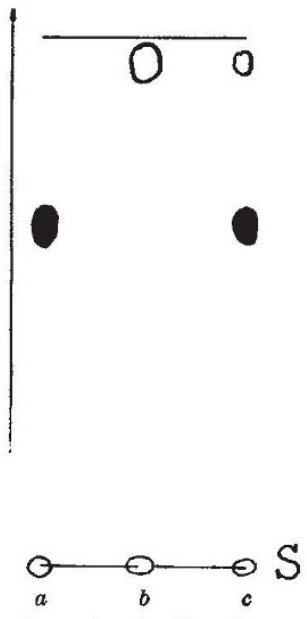

Fig. 1. Paper chromatography (methanol : acetone $=1: 1$ ). $\quad(a)$ 2,2,6,6-tetramethyl-4-ethyl-4-hydroxypiperidinoxyl ; $(b)$ triacetoneaminoxyl; $(c)$ paramagnetic red oil

An individual paramagnetic compound with a melting point of $67^{\circ}-69^{\circ}$ was obtained on chromatographic purification of the crude product on aluminium oxide (found: 0.480 per cent $\mathrm{H}$ (active); molecular weight 199.4; spin/mole $5.0 \times 10^{23}$; calculated: 0.503 per cent $H$ (active); molecular weight $200 \cdot 3$; $\mathrm{spin} / \mathrm{mole} 6 \cdot 0 \times 10^{23}$ ).

The new free radical represented an orange-yellow crystalline compound, soluble in water and in organic solvents, suffering no change for a year under the usual conditions.

The ultra-violet $\left(\lambda_{\max } 227\right.$ and $235 \mathrm{~m} \mu$ ) and infra-red absorption spectra (Fig. 2) were found to be identical to those of 2,2,6,6-totramothyl-4-ethyl-4-hydroxypiperidinoxyl obtained by direct catalytic oxidation of $2,2,6,6$-tetramethyl-4-ethyl-4-hydroxypiperidine by the scheme:<smiles>CCC1(O)CC(C)(C)NC(C)(C)C1</smiles><smiles>O=[W]O[Na]</smiles><smiles>CCC1(O)CC(C)(C)N(O)C(C)(C)C1</smiles>

The electron spin resonance spectrum of the crystalline radical represented a singlet type curve. When the sample was solved in benzene, it turned into a triplet similar to the initial ketone radical spectrum (Fig. 3).

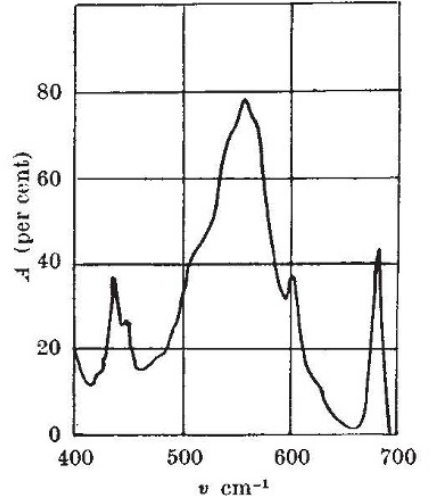

Fig. 2. Infra-red spectrum of a solid free radical

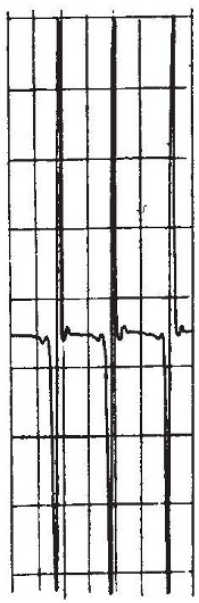

Fig. 3. Hyperfine structure of a free radical electron spin resonance spectrum

The low-intensity doublets in the hyperfine structure of the spoctrum (splitting of $5 \cdot 4$ gauss) seem to be due to an admixture of a natural carbon-13 isotope (spin 1/2).

M. B. NeIMAN

E. G. RozANTZEV

Institute of Chemical Physics, YU. G. Mamedova Academy of Sciences, Moscow.

${ }^{1}$ Rozantzev, E. G., Mamedova, Yu. G., and Neiman, M. B., Izr. Akad. Nauk SSSR, Otdel. Khim. Nauk, No. 12, $2250(1962)$.

${ }^{2}$ Neiman, M. B., Rozantzev., E. G., and Mamedova, Yu. G., Nature, 196, $472(1962)$.

${ }^{3}$ Rozantzev, E. G., and Papko, R. A., Izv. Akad. Nauk SSSR, Otdel. Khim. Nauk, No. 3 (1963).

\section{A Direct Hydrocarbon/Air Fuel Cell}

A CONSIDERABLE amount of offort is boing oxpended at present to devolop fuel cells capable of burning hydrocarbons directly and officiontly to carbon dioxido and water. Most of the work so far has been confined to temporatures below $100^{\circ} \mathrm{C}$ using sulphuric acid as tho electrolyte and platinum metals as the catalytic surface. Under these conditions it has beon possible to demonstrato current densities of up to 10 or $20 \mathrm{~m}$.amp/ $/ \mathrm{cm}^{2}$ at very low cell voltages, leaving in considerable doubt the feasibility of making efficient working devices.

We have carried out investigations using phosphoric acid of various concentrations as the electrolyte up to temperatures of $220^{\circ} \mathrm{C}$, also using platinum for the electrode catalytic surface. Fig. 1 shows the polarization obtainable on simple platinum black electrodes using propane as the fuol. Polarization is shown versus the reversible hydrogen electrode in the same electrolyte. It can be seon from these results that current densities 